\title{
China's and India's Search for International Status through the UN System: Competition and Complementarity
}

Kate Sullivan de Estrada and Rosemary Foot

\begin{abstract}
As rising powers, China and India both perceive the United Nations as a primary venue for status seeking, and both express pride in narrating the ways in which they have supported the UN Charter and the maintenance of international peace and security. Given the competitive dynamic between these two countries, we might expect this competition to extend to their activities in global governance. In this article we develop and apply the concepts of 'status domain' and 'status good characteristics' to examine the extent to which Sino-Indian status competition is exacerbated or mitigated in three status-bearing areas: UN peacekeeping operations, Security Council membership, and Security Council behaviour. We find that status competition between the two countries, at least within the UN, is not always the dominant outcome. International organizations that allow for separate status domains, and also for the expression of a shared global vision, can mitigate status competition between states.
\end{abstract}

\section{Introduction}

It has been widely argued that both China and India have been highly sensitive to matters of international status, where status is understood as both a ranking in a status 
community, as well as an expression of a state's identity with and within a valued group (Renshon, 2017, Chapter 1). This Chinese and Indian concern with status is for broadly similar reasons (Basrur \& Sullivan de Estrada, 2017; Deng, 2008; Foot, 2001; Hurrell, 2006; Miller, 2013; Pu, 2017; Larson and Shevchenko, 2010), and can be understood in both positive and negative ways.

Positively, China and India see themselves as 'civilization states' and lay claim to glorious ancient civilizations (Zhang W., 2012; Kumar, 2002). Both consider themselves as a different type of country with specific, novel contributions to make to the conduct of international politics (Sullivan 2014, p. 642; Yahuda 2011, p. 141). Each also demonstrates pride in a unique — but in each case distinctive — ability to hold together a vast population and geographical area, and to modernize an economy that for decades knew mainly poverty and disarray. China's frequent references to the 'Chinese characteristics' attached to its political-development model underlines Beijing's belief in its uniqueness and the value of a domestic political system that offers an alternative to the democracy of the West. For India it is embodied in the 'example' of a developing country that has been able to reconcile Western liberal democracy with great diversity (Zhang W., 2012; Sullivan, 2015).

Negatively, China and India also suffered grievously at the hands of the colonial powers, an experience that generates a consciousness of national humiliation that runs deep for two countries that have claimed civilizational greatness (Miller, 2013). From that humiliation has come a sense of entitlement, a quest for restitution, and a demand for respect (Newman and Zala, 2018). 
In this article, we explore the policy effects of China's and India's concern with international status through an examination of their behaviour within the United Nations (UN). We argue that China's and India's relatively similar historical experiences, conceptions of world order, and the prominence they each give to the UN have led to the adoption of quite similar strategies of status seeking within the world body. Both have sought to advocate on behalf of the developing world as well as to derive status benefits from a prominent role in UN peace operations.

The central question to which this article seeks to respond is as follows: how do two states that are recognized as strategic rivals $(\mathrm{Pu}, 2018)$ operate with respect to one another within a status environment that both view as important and that both approach in broadly similar ways? Sino-Indian rivalry is deep-seated and difficult to manage, let alone to subdue (Garver, 2016). It could be expected that neither state would be able to isolate the effects of this competition outside the UN system on their behaviour within that organization and that each would use the UN as a venue to diminish any status benefits that either may be deriving from their current roles as UN member states. However, rather than automatically engaging in status competition, as the Introduction to this Special Issue implies that they might, we argue that there is a great deal of contingency associated with China's and India's search for status, and that status competition is not the dominant outcome in all circumstances.

In particular, we contend that two key dimensions of contingency influence the degrees of status competition between China and India within the UN body. First, are the spheres in which they compete, which we refer to as 'status domains'. China and India occupy different institutional positions within the apparatus of the UN, with 
China but not India recognised as a permanent member of the Security Council. This differential positioning creates separate status domains that have- - so far - helped to contain Sino-Indian status competition. To exemplify this, we show how India has sought to frame itself as the largest historical contributor of UN peacekeeping troops among the entirety of the General Assembly membership, while China can claim that it is the largest contributor of troops among the Permanent Five (P5) of the Security Council.

The second dimension of contingency is the nature of the status issue itself, that is, whether the status good characteristics are 'zero-sum' or whether they are considered 'club' goods (Lake, 2014; Pu, 2017). Zero-sum status good characteristics tend to increase status competition, while 'club' goods mitigate status competition. This can be seen especially clearly, we argue, in relation to the issue of India's desired permanent membership of the Security Council. While the status recognition that India seeks as a permanent member has been characterised as a 'club good' - a benefit available to all members (Lake, 2014; Pu, 2017)—for China, India's institutional equivalence with China in the United Nations contains some zero-sum elements. Conversely, the record of India's behaviour as a non-permanent member of the Security Council shows that Chinese and Indian voting practices, when addressing core problems of peace and security through the UN, have frequently been complementary, owing to their shared visions of global order. This is suggestive of how the two countries could cooperate in a mutually beneficial or 'club good' manner, if India gained Council membership. 
In order to demonstrate the contingent nature of Sino-Indian status seeking within the United Nations, first, we set out our understanding of the concept of status in world politics, and in particular of the concepts of separate and shared status domains, as well as status good characteristics, referencing the ideas of 'zero-sum' versus 'club goods' in the realm of status seeking. Next, we examine where in the UN system China and India seek status and why we think this is so, linking in the concepts of status, status domains and status good characteristics. Specifically, we apply our concepts of status domain and status good characteristics empirically to gauge the extent to which Sino-Indian status competition may be exacerbated or mitigated in three status-bearing areas: UN peacekeeping operations, Security Council membership, and Security Council behaviour.

Overall, in terms of our understanding of the status-seeking behaviour of emerging powers, our contribution argues that China's and India's search for status is contingent in relation to at least two dimensions — status domains and status good characteristics - and that status competition is not a foregone conclusion. This may be so especially within international organizations that in terms of their design or as a result of the ambition of their objectives allow for separate status domains, but also for the expression of a shared global vision.

\section{The Conceptualization of Status}

Recent scholarship on status in world politics distinguishes between a state's social status and its material position within the international system (Paul, Larson, \& 
Wohlforth, 2014). Predominantly a social and perceptual phenomenon, status refers to a state's positioning in a social hierarchy, and the identity that arises from that positioning (Renshon, 2017). Positive status may derive from a state's perceived conformity with socially-valued normative standards of behaviour (where material capability may be required to enact such normative standards); from a state's possession of socially-valued material attributes; and/or from a state's close association with high-status states (Basrur and Sullivan de Estrada, 2017, pp. 2; 1012).

Larson et al (2014, p. 7) define status as 'membership in a defined club of actors and as relative standing within such a club,' while Ringmar (1996, p. 81) posits that status seeking occurs in a 'circle of recognition'. Since status concerns itself with social relations among a defined group of states, it is clear that a status-seeking strategy will be calibrated to a specific social and historical context (Wohlforth, De Carvalho, Leira \& Neumann, 2018). This means, we argue, that greater attention must be paid to the contingency of status-seeking actors and the club contexts in which they operate. In particular, states have agency in how they frame their strategies of status seeking, in which arenas they choose to seek status, and to which audiences or 'circles of recognition' they appeal in doing so.

Rather than assuming that China and India — as strategic rivals that seek status in similar ways - will automatically engage in competitive status-seeking within the UN body, we seek to gain analytical and empirical purchase on the contingent nature of Chinese and Indian status seeking. Analytically, we draw upon two concepts that have 
been articulated in the growing secondary literature on status in world politics, and we take these further.

The first is the concept of 'status domain', which may be shared or separate. A status domain is a focussed arena of state behaviour with a specified audience or "circle of recognition'. David Lake (2014, p. 247) has argued that status should be thought of as multidimensional and that states may indeed choose to compete 'in different arenas and through different strategies'. These references to separate domains are also implied in what Larson and Shevchenko (2010) label as a socially creative behavioural form, where the domain refers to separate ranking systems that can serve to reduce or remove the levels of status competition. Shared domains, on the other hand, may invite high levels of status competition, unless mitigated by other valued contextual factors. A status domain may also be only partially shared: two states may seek status in the same arena of state behaviour but vis-à-vis distinctive audiences.

Second is the notion of status good characteristics, where the latter are often summed up in the phrases 'zero-sum' status goods, versus 'club goods' (Lake, 2014, p. 251). A zero-sum status good will invite competition because where one state loses, another gains. Club goods, on the other hand, are assumed to be 'multi sum' because they promise roughly equivalent status to all members of a given group (Lake 2014: 251). We question whether these binaries can be held as tightly as these formulations tend to imply, and certainly would suggest that when perceiving of status as an identity, the size of the club, and the numbers of those seeking membership at any one time, matter to the amount of status benefit derived from membership, and that club size is 
not necessarily as 'stretchable' as has been implied (Renshon, 2017, p. 34; Lake, 2014, p. 251).

The former idea of status domains when applied to the United Nations suggests the possibility that the institutional design of the UN (and potentially of other international organizations) may make it possible to operate in separate status domains, as well as in shared status domains (e.g. the UN General Assembly and the UN Security Council). This design, thus, immediately complicates our understanding of the circumstances in which status competition may increase or decrease. Moreover, where separate domains carry within them the notion of ranking or relative standing, then this weakens the notion of separateness. In this instance, they are less likely to mitigate the levels of status competition and instead lend themselves to promoting status rivalry, as in permanent versus non-permanent membership of the Security Council, or the P5 versus the General Asssembly. As Paul, Larson and Wohlforth (2014) argue, when status is experienced in the form of a positional good - one that is collective, subjective and relative - it is presumed to lead to the deference of others. This makes positional status a particularly valued attribute for any state seeking to satisfy its policy interests in a multilateral body like the UN.

\section{The Perceived Sources of Status within the UN System}

How might the ideas of status domain and status good characteristics be applied to Chinese and Indian behaviour in the UN, where both are concerned with status and desire the authority and deference that may flow from having a recognized high status in world politics? Where do they each look for sources of status? 
At the broadest level, China and India both agree on the significance of the United Nations in world politics. Both states endorse a central role for the UN in the management of international peace and security and place faith in a traditional Westphalian interpretation of the norms of state sovereignty contained within the UN Charter. They recognize the Charter and UN design as providing some strategic benefits - that is, the UN can operate to constrain the power of the most powerful in world politics, and to demonstrate that in some domains the world is indeed multipolar.

In terms of our focus on international status, both perceive the organization as capable of providing valued benefits. Beijing and New Delhi understand UN membership as a welcome response to that demand for restitution for past slights - a benefit that all former colonial states acknowledge. The formal recognition attached to UN membership is a signal of legal sovereign equality and, via the UN General Assembly, of an opportunity equally to voice demands in an otherwise hierarchically structured global order. In addition, the UN allows states such as China and India to demonstrate their willingness to bear the responsibilities associated with great power status. Status can come either through permanent or elected membership of the Security Council, for example, or prominent involvement in core UN activities such as UN Peace Keeping Operations (PKOs).

In order to understand the extent to which status competition can be exacerbated or mitigated, the following three sections combine our analytical frames of status domain and status good characteristics with an empirical analysis of Sino-Indian 
status competition. We argue, first, that status competition through UN peacekeeping operations is mitigated to some extent by partially separate status domains.

Second, we contend that for China, the question of India's membership of the Security Council is predominantly zero-sum even though Council membership is discussed generally in the status literature as a club good that is not zero-sum $(\mathrm{Pu}$, 2018; Lake, 2014). This is because permanent membership is, for China, a particular kind of identity that India's membership in particular would directly challenge: for example, it would underline their relative positions within a shared status domain, including degrees of association with developing countries, and allow for comparison of the priority they each give to participation in peacekeeping operations.

Third, we examine the record of India's non-perm membership of UNSC in order to shed light on Chinese and Indian practice in the UN. Here we find status competition mitigation behaviour, whether intended or not, deriving from their shared visions of global order. These shared visions have led to complementary approaches to some of the core problems of peace and security addressed by the Security Council which, in turn, is suggestive of how they could operate if India became a permanent member. While there are both potential drawbacks and benefits of this shared vision, we note that China and India could unite, perhaps with Russia, on certain key issues to challenge the authority of the United States and its core allies of France and the United Kingdom (the P3) on the Security Council.

\section{China, India and Peacekeeping Operations}


Contributing to core UN functions offers an avenue through which China and India pursue status. Peacekeeping operations have emerged as a central institution through which China and India seek to underscore their financial and 'human' contributions to the maintenance of international peace and security. In this area of UN activity, we find neither strong elements of zero-sum nor strong multi-sum dynamics since China and India's variegated approaches help to mitigate, though not remove entirely, some areas of status competition. The two states offer their contributions sometimes in separate and sometimes in similar ways, and they reduce status competition through drawing attention to their contributions in different status domains.

India's troop contributions to peace operations, financial contributions to the UN budget, and its provision of peacekeeping training facilities raise the prospects of status competition with China but to different degrees. With regard to troop contributions to UN peacekeeping missions, India has an unparalleled historical record, dating back to the 1950s. The total contribution of approximately 195,000 Indian troops is the highest of any country, and India has participated in more than two thirds of all UN peacekeeping operations mandated to date (PMIUN, 2018). Throughout 2018, India ranked as either the third or fourth highest contributor of peacekeeping personnel (including police, $\mathrm{UN}$ military experts on mission, staff officers and troops) on a monthly basis, averaging a contribution of 6,667 peacekeepers per month across the year (United Nations Peacekeeping, 2018).

India's UN officials and political and diplomatic elites have consistently invoked their country's superlative track record compared with other UN member states. Moreover, 
since the early 1990 s, India has made frequent reference to its contributions to peacekeeping in support of its claim to a permanent seat on the Security Council (Krishnasmay \& Weigold, 2003; Hansel \& Möller, 2014). During India’s stint as a non-permanent member of the UN Security Council from 2011-2013, Indian representatives focused on peacekeeping as a core agenda and made proposals to improve its effectiveness (Mukherjee, 2015).

Often referred to the as 'backbone' of UN peacekeeping (Mukerjee, 2015; Vira, 2012), Indian troops are held in high regard for their high levels of discipline, skill and training, and India has receive a number of commendations, both from the UN Secretariat and the United States (Schaffer, 2009; Krishnasamy, 2001). Following allegations in 2013 of small numbers of Indian troop involvement in sexual exploitation and abuse by UN peacekeepers, the Indian government responded robustly through disciplinary proceedings, the declaration of a zero-tolerance policy, and support for a UN trust fund in support of victims (Kaul, 2018). This swift and visible response underscored India's commitment to upholding its reputation as a core contributor of well-trained and well-behaved troops.

India provides a UN peacekeeping training facility, the Centre for United Nations Peacekeeping, that had trained 800 troops from 82 countries by 2015 (Modi, 2015). In recent years, India has worked together with the United States to deliver three editions of a United Nations Peacekeeping Course for African Partners in New Delhi, a collaboration that not only nominally positions the United States and India as equal partners in expertise, but provides an opportunity for the United States to rhetorically celebrate India's historic contribution to peacekeeping missions (Strike, 2018). 
India's high troop contributions continue despite domestic controversy in recent years over a 'mismatch between UN mandates and resources' in missions where Indian forces are deployed, and over acknowledgement that India has suffered the highest historical loss of personnel through UN peacekeeping operations (Vira, 2012; PTI, 2018). Indian representatives at the UN have argued that India should have a greater say in decisions relating to peacekeeping (Permanent Mission of India to the UN 2018). Indeed, Prime Minister Modi (2015) made the point in 2015-implicitly ignoring the role of China - that 'Troop Contributing Countries do not have a role in the decision-making process' and 'do not have adequate representation in senior management and as Force Commanders'. Nonetheless, the Modi government committed to increasing India's troop contributions in 2017 (Hindustan Times, 2018).

India's commitment persists, some argue, because the provision of troops bolsters India's international status directly (Krishnasamy and Weigold 2003), and because, as mentioned, the historical size and quality of India's troop contributions enhance India's likelihood of attaining a permanent seat on the UN Security Council (Hansel \& Möller, 2014). China's increasing contributions to UN peacekeeping, outlined below, have likely raised the value of India's own contributions, although at least one observer asserts that India 'resents the disproportionate attention Chinese contributions receive' (Vira, 2012). This view suggests that for India, troop contributions to UN peacekeeping constitute a shared status domain, albeit one in which India's historical troop contributions remain unsurpassed by some margin. 
In comparison to India's provision of personnel, New Delhi's financial contribution to the UN peacekeeping budget is proportionally very low, with its country contribution set at 0.15 percent for $2017-2018$. This calculation is based on a UN-agreed formula that takes into account the relative economic wealth of Member States (United Nations General Assembly, 2015). These UN decision rules provide a justification for India's comparatively low contributions and thus likely mitigate against direct competition between India and China on this issue. Indeed, Indian UN representatives have at times underplayed the importance of financial contributions to the United Nations in absolute terms, arguing that these are, and should remain, calculated on the basis of a Member State's ‘capacity to pay' (Sreenivasan, 2008, pp. 117-8).

China does not match the level of India's troop contribution (not least because of a lack of language capacity) or the deployment experience that India has gained over these many years of participation in PKOs. Throughout 2018, China typically ranked as the eleventh highest contributor of peacekeeping personnel on a monthly basis, averaging a contribution of 2,476 peacekeepers (including police,UN military experts on mission, staff officers and troops) per month across the year (United Nations Peacekeeping 2018). Beijing came much later than New Delhi to participation in peacekeeping, its decision to provide engineering troops and military observers in the UNPKO in Cambodia in 1992 marking a significant change. Before then, in the 1970s, it viewed such operations with suspicion, and then in the 1980s only offered modest levels of support (Hirono \& Lanteigne, 2011, Zhang Y., 1996).

However, from the 1990s onwards, the mode of China's and India's contributions began to coincide even as the numbers of Indian peacekeepers continued to dwarf 
those that China felt able to provide. In its Position Paper presented to the UN General Assembly in September 2016, the Chinese government stated that it had contributed more than 30,000 peacekeepers over the years since its first involvement and that in 2016 more than 2,600 were providing their services in the then 10 ongoing operations (MoFA, 2016). In December 2018, an article in the People's Daily, an official newspaper of the Central Committee of the Communist Party of China, provided an update on these figures and noted a contribution of 38,000 peacekeepers operating in $24 \mathrm{UN}$ missions since China's first participation in such operations. Moreover, the article remarked approvingly on China's provision during these peace operations of over 200,000 medical interventions and the building of 16,000 kilometres of roads (People's Daily, 2018).

While this matter of relative troop contributions may appear as an area of potential status competition with India, it is mitigated by China's efforts to promote its status as a contributor to peacekeeping within a separate status domain. China frequently mentions that it offers more peacekeeping troops than all other of the permanent members of the Security Council combined, signalling that its competition for status in this policy area is with other permanent members of the Security Council. It rarely if ever mentions other troop contributing countries by name, though it voices general sympathy for their calls for reining in the scope of the often overly ambitious peace operations' mandates. Not only is China's contribution as a P5 member frequently referenced in positive terms by China itself but also by UN Secretaries-General. Ban Ki-moon, for example, in 2013 praised China's solidarity with the UN and, mirroring Chinese statements, he noted that Beijing provided more peacekeepers 'than all of the four other permanent members put together' (Ban, 2013). Indeed, Chinese 
peacekeepers have often been 'commended for their discipline and professionalism' and mostly have had an unblemished record (Huang, 2011).

China's advances in international status are also built upon its contributions to UN finances. Beijing's contribution to the peacekeeping budget has steadily increased, reflecting its current position as the world's second largest economy. However, P5 members are required to pay more whatever their GDP because, as the UN puts it, 'of their special responsibility for the maintenance of international peace and security' (UN Peacekeeping, 2018).

As of 2016, China became the second largest contributor to that budget, providing 10.25 percent of the operating costs in 2017-2018 with an assessment of 12 per cent for 2019-2020. Given the agreed formula for calculating budgetary contributions, this area similarly is not a major source of status competition with India though it could be a source of leverage for China within UN policy-making more broadly.

Certainly, China like India provides peacekeeping training centres for the training of troops from other countries as well as for the Chinese People's Liberation Army forces. However, the numbers trained in these facilities remain small (1500 for China as of 2018 from more than 60 countries [People's Daily, 2018]) and the UN's needs are great, thus similarly mitigating any status competition with India on this issue.

However, in other respects China has projected a lofty position of moral responsibility deriving from its privileged position as a P5 member which it implies those below this level are not expected to emulate. As President Xi explained to UN Secretary General 
Ban Ki Moon in June 2013, he understood that China, 'as a permanent member of the UN Security Council' had 'heavy responsibilities to assume,' adding that Beijing had 'the capability to assume them' (Xinhua, 2013).

Later on, Xi additionally emphasized the country's capacity to provide a wide range of public goods to the United Nations. In a speech made in 2015 to the UN General Assembly in response to President Obama's decision to step up the US role in peacekeeping, and to host that year a special and historic leaders' summit on peacekeeping, Xi offered a sizeable increase in Chinese largesse. Xi's financial pledges went well beyond anything that developing countries such as India could offer, explicitly promising $\$ 1$ billion for a 10 -year China-UN peace and development fund, the creation of a permanent Chinese peacekeeping police squad, and a standby force of 8,000 troops (Xi, 2015). With specific reference to African needs, Xi pledged a \$100 million military assistance grant to the African Union over five years to support the establishment of an African Standby Force and the African Capacity for Immediate Response to Crisis unit (Xi, 2015). Yet, there is little evidence that this represented direct status competition with India; instead, status positioning for China appeared to be related to its privilege of P5 membership and mainly in the status domain of other P5 members, in this instance the United States in particular.

In sum, India's and China's levels of status competition in the key area for the UN of peacekeeping are constrained and aided by the decision rules of the UN itself (as with respect to the budget contribution) and as a result of their positioning within the separate domains of the UN General Assembly and UN Security Council. This 
suggests, of course, the possibility that Security Council permanent membership for India could serve to disturb this equilibrium, a topic that we turn to next.

\section{India's Membership of the UN Security Council}

It is widely acknowledged that permanent membership of the Security Council stands as perhaps the most coveted prize for status-seeking rising powers. ${ }^{1}$ Bearing 'primary responsibility for the maintenance of international peace and security' pursuant to Article 24(1) of the UN Charter, the Security Council is the UN's most powerful forum, even more so since the Council has emerged from relative marginalization during the Cold War to a surge of activity since the 1990s (Hassler, 2013; Malone, 2007).

The high status of the existing P5 manifests itself in both the rights and duties accorded to these great powers and, as a consequence, the enormous symbolic power attached to the Council and its processes (Hurd, 2002). The value of a permanent veto-wielding seat on the Council is further underscored by the P5's failure to identify a shared formula for Security Council reform, despite the groundswell of support for such reform that has emerged since 1992. India formally announced its own bid for a permanent seat in 1994 (Sreenivasan, 2008), later joining with Brazil, Germany and

\footnotetext{
${ }^{1}$ Non-permanent membership of the Council, too, while a lesser prize, is also considered as a short-cut to status (Malone 2000). This helps to explain why India, even while refraining from courting permanent membership during the Cold War period, served on the Council as an elected member six times, and took up a seventh term from January 2011 to January 2013.
} 
Japan in an effort to reshape a Council that, while it reflected the 1945 post-war settlement, no longer appeared representative or commanded the respect that existed at that earlier stage.

Certainly, India recognizes the value of the status that comes from permanent membership of the UN Security Council, and membership is among the most central of New Delhi's status-seeking goals as a rising power (Basrur and Sullivan de Estrada, 2017, p. 92). Preoccupation with the question of Security Council reform among both India's political elite and its emerging middle classes has grown markedly since India first made its bid for a permanent seat in 1994. India's diplomatic activism is three pronged: it has targeted the broader institutional and procedural requirements of reform; it has sought common cause with the 'Group of Four' (comprising India, Brazil, Germany and Japan) since 2004 and the L.69 grouping (a cross-regional grouping of 42 developing countries that seek expansion of the Council in both the permanent and non-permanent categories) since 2007; and it consistently seeks individual state endorsements for Indian permanent membership during bilateral state visits. However, so far New Delhi's activism in this regard has come up against the hard reality that the drawing up of a common blueprint for Council reform among the membership of both the General Assembly and the Security Council has been impossible to achieve.

The lack of agreement on the terms of any reform among some significant members of the P5 is a puzzle that attention to the academic literature on social status exposes. Permanent membership is often considered to be an identity (such as status as a major power and nuclear weapons state), otherwise termed a 'club good' in these academic 
treatments of international status (Lake, 2014; $\mathrm{Pu}, 2018$ ). Were India or others to join the Security Council, this literature implies, this need not mean a significant diminution in China's or other P5 member states' status. Yet the blockages to opening membership to others seem formidable.

Competing formulas for reform and concerns over the efficacy of an expanded Council are just two of the factors that stand in the way of a Council with expanded membership. However, we argue that when considering status competition between China and India as a potentially primary obstacle, the latter's membership of the Security Council may not actually be perceived as a 'club good' for China, and this may well explain China's stance on India's claim for permanent membership. That stance is ambivalent. While Beijing's position on India's bid certainly compares favorably to its position on Japan's equivalent bid, which is widely opposed in China (Miller, 2013), nevertheless China has opted for a consistent formulation of an ambivalent position over several years (Kaura, 2015).

The first explicit reference to India's specific aspirations in the Security Council came in October 2004, during a visit of the Chinese State Councillor and former Foreign Minister Tang Jiaxuan to New Delhi, when he endorsed, for the first time, 'a bigger role for India in the international community, including in the United Nations Security Council' (Tang, cited in Malik, 2005, p. 22). This formulation has remained remarkably constant over time, with Xi Jinping (2014) again declaring in a statement made at the Indian Council of World Affairs in New Delhi, that 'China supports India in its aspiration to play a bigger role in the United Nations, including in the Security Council,' a statement that neither explicitly endorses India's bid, nor closes down the 
possibility of doing so. Its ambivalence in part reflects China's broader uncertainty about the best way to achieve reform of the Security Council, but it also reflects, we argue, the zero-sum elements that China perceives in relation to this question.

Four main elements of India's putative membership make this a question of relative rank in a status community for China and potentially zero-sum. First, and probably of most significance for Beijing, Asia is a continent that China seeks to lead and at present it is the one Asian state on the Security Council. India's membership would raise the levels of competition in both these matters of Asian identity and Asian leadership. As Malik (2005, p. 26) argues, 'China does not want any other major Asian country to sit on the council as an equal.'

Secondly, China still claims identity as part of the developing world (as well as an identity as a major state), and is the sole developing country representative among the P5 on the Security Council. India, however, implicitly casts doubt on this Chinese claim of representation. In the early to mid-1990s, when India made its first explicit bid for a seat on the UN Security Council, India staked its claim on the basis of its identity as a developing country, implying that a developing country would behave more equitably and inclusively than the current membership (Basrur and Sullivan de Estrada, 2017). Indeed, Pranab Mukherjee, the Indian Minister who first announced India's claim to a permanent seat before the General Assembly in October 1994, argued that India's inclusion as a developing country would 'reflect the universal character of the world body' (UNGA, 1994, p. 15). Claims that India's inclusion would bring greater 'representativeness' to the Security Council have continued (Sullivan and Moussavi, 2015). 
Thirdly, China's position as the main permanent member of the Security Council to contribute to peacekeeping forces would immediately be challenged, even if its budget contributions continued to far exceed those of India.

Finally, there is the more general point that support for Indian membership could lead to changed rules on the usage of Security Council vetoes, as well as resulting in the entry of several other new members. The former would diminish the strategic benefit of permanent membership for China (as well as for other of the P5 members), and the latter would dilute the club good characteristics associated with the status of being a permanent member. As Renshon (2017, p. 34) has argued, 'the status associated with becoming a member of [a] group is to a large extent fixed.' He goes on, '[t]hus every additional member of the group inevitably lessens the value associated with it' $-\mathrm{a}$ "classic definition of "zero-sum"”.

However, we are reluctant to reject the notion that permanent membership for both China and India in the Security Council does not retain some 'club good' characteristics. Thus, in our final substantive section, we reflect on how these zerosum characteristics, even in this critical status club of the Security Council, could be mitigated for China and India.

\section{Chinese and Indian Practices in the UN Security Council}

Above, we argued that India's permanent membership of the Security Council would result in the institutional equivalence of China and India, thereby instantaneously 
creating shared status domains and therefore increasing the potential for status competition. Here, we also posit the opposite: the possibilitity that permanent membership for both China and India could in fact come to be seen as having club good benefits over time. Specifically, iterative collective action within the Council on the part of China and India could benefit the world order vision that these two states would like to see more firmly established, thus mitigating their bilateral status rivalry within the UN framework.

We find that there are strong complementarities between China and India in the United Nations, particularly with respect to issues relating to humanitarian intervention, responsible sovereignty, and the related 'Responsibility to Protect' as well as in the functional area of peacekeeping, already discussed. We briefly examine these complementarities with respect to three major issues that have generated controversy within the United Nations in the post Cold War era: first, the UN role in response to the Iraqi intervention in Kuwait in 1990-91 and second, with respect to Libya and Syria in 2011-13. Both responses coincided with periods during which India served as an elected member of the Security Council. Thirdly, we examine the Indian and Chinese approaches to the norm of the 'Responsibility to Protect' (R2P), first agreed to in the World Summit Outcome document of September 2005. All three issue areas illustrate the similarities in the Chinese and Indian positions.

The post-Cold War period presented both China and India with new vulnerabilities. The Chinese government faced major state condemnation after the Tiananmen bloodshed of 1989, while India lost its primary international partner, the former Soviet Union. Both governments responded by cleaving more tightly to a conception 
of world order that stressed the legal sovereign equality of states and the associated norm of non-interference in internal affairs.

Neither, however, could prevent the slow and halting development of a more activist and interventionist UN in the 1990s. Kofi Annan as Secretary-General, as well as his predecessor Boutros Boutros-Ghali, gave impetus to a redefinition of sovereignty that meant more than the recognition of the sovereign rights of states, but also included the protection of individual human beings from large-scale abuse, often inflicted by their own governments.

The Iraqi invasion of Kuwait in August 1990 was a pivotal moment in the post-Cold War functioning of the UN Security Council, ushering in a new, if temporary, phase of unanimity among its permanent members (Malone, 2007). However, although both China and India deplored the Iraqi invasion as a violation of Kuwaiti sovereignty, the decision to use force as well as the scope of the military campaign deepened their concern about the probable consequences of entering an era that witnessed unprecedented levels of Soviet-American cooperation (Cockayne \& Malone, 2008, p. 385). The historical references associated with UNSC Resolution 678, that authorised Operation Desert Storm and was passed in November 1990, were particularly troubling for China and led it to abstain on that resolution despite coming under US pressure to vote in favour. It was the first time military action against an 'aggressor state' under Chapter VII had been used since the Korean War-a time when the UN had labelled China itself as an aggressor state (Foot, 1995, p. 26). 
Taking up non-permanent membership of the Security Council from 1991-2, India, like China, similarly feared that the Gulf War augured a newly political and militarily intrusive role for the Security Council, led by the United States and its allies (Dixit, 1996, p. 44). Indian concerns centred, in particular, on the provisions of UNSC Resolution 687, which, after the ceasefire and liberation of Kuwait, imposed a host of regulatory mechanisms on Iraq. After a long and drawn out Council meeting, both India and China voted in favour of Resolution 687 but it was grudging support (Sreenivasan, 2008, p. 104). Both countries subsequently abstained on Resolution 688, which condemned Saddam Hussein's repression of the Kurds and recorded that the refugee flows that resulted represented a threat to international peace and security. Beijing and New Delhi were both leery of the potential establishment of a principle of intervention for humanitarian purposes (Sreenivasan, 2008, p. 104). The two states suspected that their interpretations of the UN Charter and UN Security Council role were being undermined during the course of this conflict with a concomitant reduction in their ability to demonstrate their centrality to the unfolding events as members of the Council.

The year 2011 opened up new controversies within the Security Council over questions of intervention, with the 'Arab Spring' prompting uprisings in both Libya and Syria that garnered international attention because of the repressive actions that the leaderships of both countries adopted in response.

In February 2011, both India and China voted in favour of UNSC Resolution 1970 on Libya, "which reminded the Libyan state of its responsibility to protect its population, demanded an end to the violence, referred the situation to the Prosecutor of the 
International Criminal Court (ICC), imposed an arms embargo on the country, placed travel bans on leading members of the government and froze regime assets overseas' (Hall, 2013, p. 85). However, both China and India abstained in March on UNSC Resolution 1973 (as did Russia, Brazil and Germany), which authorized a no-fly zone and 'all necessary measures' to protect Libyan citizens.

India backed UNSC 1970 in part because it had unanimous support and because it demonstrated New Delhi's willingness to contribute to the global management of peace and security - the central function of the UN Security Council. However, India's lack of support for Resolution 1973 was justified officially on the grounds that political efforts to address the situation had not gone far enough, that there was limited 'credible information on the ground', and that the 'sovereignty, unity and territorial integrity of Libya' must be respected (Government of India, 2011). China found itself in close alignment with Indian thinking on the Libyan case. The decision of both countries to support Resolution 1970 was made easier because the Arab League, the African Union as well as the Organization of the Islamic Conference all issued strongly worded statements abhorring the Gaddafi regime's attacks on civilians. Neither China nor India would easily have stood alone against this level of unanimity. Resolution 1973 evoked a more circumspect response, however, with China's UN ambassador arguing that the UN Charter needed to be respected and peaceful measures were necessary to end the crisis. He also mirrored India in asking for the efforts of the UN's Special Envoy, the AU and Arab League to be allowed to continue (UNSC, 2011a). 
In the case of Syria, where the internationalized civil war is still ongoing though at a diminished level, several significant draft Security Council Resolutions have attracted Chinese and Russian vetoes. Six of these vetoes have been cast by China, a most unusual stance for a government that, since it took over the Security Council seat in 1971, has used its veto on only 12 occasions in total. Both Beijing and Moscow blocked an attempt at a resolution in October 2011 that would have condemned human rights violations in Syria, demanded the cessation of the use of force against civilians by Syrian authorities, and threatened the use of sanctions (UNSC, 2011b). They blocked another important resolution in February 2012 which similarly condemned the escalating violence, and gave support for the Arab League's decision in January 2012 to facilitate a Syrian led political transition. India chose to abstain on the 2011 resolution but, in direct opposition to China, to vote in favour of the 2012 draft.

Despite the divergent responses to the February 2012 resolution, India's and China's explanations for their voting stances were remarkably similar. China vetoed because, while the military conflict in Syria had caused 'significant civilian casualties, a fact that should attract the attention of the international community' the issue was 'a domestic one by nature, since Syria did not have disputes with its neighboring states, nor did it threaten to use force against its neighbors or wage a war of aggression against any states' (Qu 2012). In a similar vein, India's position was 'that a political process for the resolution of the present crisis should be led by the Syrians themselves' (UNSC, 2012). Both saw the UNSC role as one of facilitation rather than Chapter VII-related mandatory action. 
Given the convergences in China and India's stances on these issues, we should hardly be surprised that China's and India's responses to R2P have similarly been complementary - in both cases, they have not been entirely obstructive but their responses illustrate an overwhelming caution.

The crux of R2P is contained within paragraphs 138 and 139 of the World Summit Outcome Document of September 2005 (UNGA, 2005). At the largest ever gathering at UN Headquarters in New York, heads of state and government agreed in those paragraphs that '[e]ach individual state has the responsibility to protect its populations from genocide, war crimes, ethnic cleansing and crimes against humanity' - often referred to as the 'four crimes.' They also agreed that if a state were to be seen to be 'manifestly failing' in that protection duty, the international community would first use 'diplomatic, humanitarian and other peaceful means' to help protect populations from the four crimes, and next be prepared to take collective action, 'on a case by case basis and in cooperation with relevant regional organizations as appropriate, should peaceful means be inadequate.'

In 2009, the UNGA adopted a three-pillar implementation structure. It was to prove crucial to the understandings that have come to be attached to the norm of R2P. The first pillar explicitly notes that it is the responsibility of the state to provide protection to its population from mass atrocities. The second pillar focuses on international assistance to help build a state's capacity to prevent atrocities. The third pillar emphasizes the need for a 'timely and decisive response' on the part of the international community, defined as the UN Security Council, were the state to fail in its protection role. 
China and India endorsed R2P as outlined in the WSOD, although in both cases their support for it was 'begrudging,' and came late because it was viewed with suspicion (Hall, 2013, p. 85; Foot, 2016). Both China and India strongly back pillars one and two, but remain wary of pillar three, which paves the way for the Security Council to consider interventionist measures if a state demonstrates a 'manifest failure' to protect its population from any of the four crimes outlined in the R2P doctrine. India's and China's opposition centres on what is seen as the self-interest of Western powers in their decisions to intervene, anxieties about their own vulnerabilities to outside interference, and acknowledgement that interventions often have long-lasting, unforeseen and undesirable consequences (Chen, 2016; Hall, 2013).

In each of the cases discussed in this section, therefore, we see overlap in their world views and diplomatic positions such that their efforts could be viewed as complementary rather than competitive. Certainly, we see a Chinese and Indian desire to protect their particular interests, but we also perceive a serious effort to protect and project a form of global order that they see as more democratic. What each seeks to secure is legal sovereign equality, thus to prevent, as Jennifer Welsh (2013: 394) has put it, the move from legal egalitarianism towards a more hierarchical system of world politics that results in state conduct being 'subject to oversight and punishment by an unspecified and unaccountable agent of the "international community". It is a position that appeals to a wide constituency in global politics, not least to those that had been subject to colonial exploitation in the past as well as other forms of external control. 
We see, then, China and India sharing a common position as states arrayed against the threat or use of force, and strongly supportive of non-intervention as well as of political negotiation as the route to conflict resolution. These shared visions of global order, we argue, create the potential for status competition between China and India to be mitigated if India were to join the Council. Since Russia, too, has frequently supported non-intervention within the decisionmaking of the Council (Allison, 2013), China and India could unite with Russia to balance against the power and authority of the United States, France and the United Kingdom. China, India and Russia each support a 'thin conception' of liberal international order, based primarily on the reciprocal recognition of sovereignty and the principle of non-intervention (Hurrell, 2003). They would each potentially enjoy a club good and club status within a larger club in this joint power-checking role. This outcome might well serve to protect their material and normative interests, as well as those interests of a wider General Assembly membership similarly concerned about the overweening power of the P3 on the Security Council. It might also, however, further erode any enabling environment for the application of the $\mathrm{R} 2 \mathrm{P}$ principle to protect populations from genocide, war crimes, ethnic cleansing and crimes against humanity.

\section{Conclusion}

If rising powers do indeed 'form a separate hierarchical order' and are thus prone to status competition among themselves (see Introduction to this special issue), and if China and India specifically have a history of strategic competition, we might expect to see a competitive dynamic at play in the interactions of these two states within the United Nations. However, even while China and India continue to jostle for status in 
Asia, this dynamic appears so far to have been tempered within the UN. One primary reason for this is that India so far has been denied institutionalized status parity with China within the Security Council. They each, at present, have chosen to construct status with respect to such core UN activities as peacekeeping in separate domains. This finding suggests that any expectation of status competition must be attentive to contingent factors that can mute or remove that competition.

At the same time, we have also argued that were they to share the same domain of the Security Council, the outcome would be more mixed. On the one hand, China would perceive its relative status position as being undermined for reasons mostly connected with its role as the developing country representative on the Council and the leading Asian state. On the other hand, here again, we see possibilities for mitigation of the rivalries that are attendant on what otherwise are positional hierarchies. These arise from China's and India's shared positions on the inviolability of state sovereignty and their common interest in countering the effects of Western dominance in world politics.

While our finding of complementarity rather than competition is surprising, we do not suggest that this pattern will necessarily hold elsewhere. China and India often adopt discordant stances in other institutions of global and regional governance: for example over India's desired membership of the Nuclear Supplier's Group, and over the terms of the Regional Comprehensive Economic Partnership, a proposed 16-member free trade agreement that includes China and India. The UN system, however, presents us with a more nuanced picture. Future research might more fully explore how an institutional design that allows for separate status domains, and also for a balancing 
role founded on a shared global vision, could potentially mitigate status competition between states within international organizations.

\section{Author Biography}

Kate Sullivan de Estrada is Associate Professor in the International Relations of South Asia, Oxford School of Global and Area Studies/Department of Politics and International Relations, University of Oxford and is a Fellow of St Antony's College, Oxford

Rosemary Foot is Professor (Emeritus) of International Relations, and currently a Senior Research Fellow in the Department of Politics and International Relations, University of Oxford, a Research Associate of Oxford's China Centre, and Emeritus

Fellow of St Antony's College, Oxford. She is also a Fellow of the British Academy. 


\section{References}

Allison, R. (2013). Russia, the West, and Military Intervention. Oxford: Oxford University Press.

Ban, K. (2013, June 19). Remarks at the China Peace-keeping Military Training Centre. Retrieved from https://www.un.org/sg/en/content/sg/speeches/2013-0619/remarks-china-peacekeeping-military-training-centre

Basrur, R. \& Sullivan de Estrada, K. (2017). Rising India: Status and Power. London: Routledge.

Chen, Z. (2016). China and the Responsibility to Protect. Journal of Contemporary China, 25(101), 686-7 00.

Cockayne, J. \& Malone, D. M. (2008). The Security Council and the 1991 and 2003 Wars in Iraq. In V. Lowe, A. Roberts, J. Welsh \& D. Zaum (Eds.), The United Nations Security Council and War (pp. 384-405). Oxford: Oxford University Press.

Deng, Y. (2008). China's Struggle for Status: the Realignment of International Relations. Cambridge, U.K.: Cambridge University Press.

Dixit, J. N. (1996). My South Block Years: Memoirs of a Foreign Secretary. New Delhi: UBSPD. 
Foot, R. (1995). The Practice of Power: US Relations with China since 1949. Oxford: Oxford University Press.

Foot, R. (2001). Chinese Power and the Idea of a Responsible State. The China Journal, 45(January), 1-19.

Foot, R. (2016). The State, Development, and Humanitarianism: China's Shaping of the Trajectory of R2P. In A. J. Bellamy \& T. Dunne (Eds.), The Oxford Handbook of the Responsibility to Protect (pp. 932-47). Oxford: Oxford University Press.

Garver, J. (2016). China's Quest: A History of the Foreign Relations of the People's Republic of China. New York: Oxford University Press.

Government of India (2011, March 18) UNSC resolution on Libya - India's Explanation of Vote. Retrived from: https://mea.gov.in/pressreleases.htm?dtl/639/UNSC+resolution+on+Libya++Indias+Explanation+of+Vote Hall, I. (2013). Tilting at Windmills? The Indian Debate over the Responsibility to Protect after UNSC Resolution 1973. Global Responsibility to Protect, 5, 84-108.

Hansel, M. \& Möller, M. (2014). House of cards? India's rationales for contributing to UN peacekeeping. Global Change, Peace \& Security, 26(2), 141-157.

Hassler, S. (2014). Reforming the UN Security Council Membership. Abingdon/New York: Routledge. 
Hirono, M. \& Lanteigne, M. (2011). Introduction: China and UN peacekeeping. International Peacekeeping, 18(3), 243-256.

Huang, C. (2011). Principles and Praxis of China's Peacekeeping, International Peacekeeping, 18(3), 23-36.

Hurd, I. (2002). Legitimacy, power, and the symbolic life of the UN Security Council. Global Governance, 8(1), 35-51.

Hurrell, A. (2006). Hegemony, Liberalism and global order: what space for would-be great powers? International Affairs, 82(1), 21-40.

Hurrell, A. (2003) Order and Justice in International Relations: What is at Stake? In R. Foot, J. Gaddis \& A. Hurrell (Eds), Order and Justice in International Relations (25-49). New York: Oxford University Press.

Kaul, A. (2018). Sexual exploitation and abuse among peacekeeping forces, and India's response. ORF Young Voices, New Delhi: Observer Research Foundation. Retrieved from: https://www.orfonline.org

Kaura, V. (2015, June 3). China on India's UNSC Bid: Neither Yes Nor No. The Diplomat. Retrieved from https://thediplomat.com 
Krishnasamy, K. (2001). Recognition for Third World peacekeepers: India and Pakistan. International Peacekeeping, 8(4), 56-76.

Krishnasamy, K. \& Weigold, A. (2003). The paradox of India's peacekeeping.Contemporary South Asia, 12(2), 263-280.

Kumar, R. (2002). India: A 'nation-state'or 'civilisation-state'? South Asia: Journal of South Asian Studies, 25(2), 13-32.

Larson, D. W. \& Shevchenko, A. (2010). Status seekers: Chinese and Russian responses to US Primacy. International Security, 34(4), 63-95.

Malone, D. M. (2000). Eyes on the prize: the quest for nonpermanent seats on the UN Security Council. Global Governance, 6(1), 3-23.

Malone, D. M. (2007). Security Council. In Weiss, Thomas G. and Sam Daws, (Eds.), The Oxford Handbook on the United Nations (pp. 117-135). New York: Oxford University Press.

Miller, M. (2013). Wronged by Empire: Post-Imperial Ideology and Foreign Policy in India and China. Stanford, CA: Stanford University Press.

Modi, N. (2015, September 29). Statement by Prime Minister at the Summit on Peacekeeping in New York. Retrieved from: https://mea.gov.in/outoging-visit- 
detail.htm?25856/Statement+by+Prime+Minister+at+the+Summit+on+Peacekeeping $\underline{+\mathrm{in}+\mathrm{New}+\text { York }}$

MoFA [Ministry of Foreign Affairs] (2016, September 7) Position Paper of the People's Republic of China at the $71^{\text {st }}$ Session of the United Nations General Assembly. Retrieved from http://www.fmprc/gov.en/mfa_eng/zxxx_662805/t1395489.shtml

Mukherjee, A. (2015, October 20). At the crossroads: India and the future of UN peacekeeping in Africa. Brookings. Retrieved from https://www.brookings.edu/research/at-the-crossroads-india-and-the-future-of-unpeacekeeping-in-africa/

Newman, E. \& Zala, B. (2018). Rising powers and order contestation: disaggregating the normative from the representational. Third World Quarterly, 39(5), 871-88.

Paul, T.V., Larson, D. W. \& Wohlforth, W. C. (Eds.) (2014). Status in World Politics. New York: Cambridge University Press.

Paul, T. V. \& Shankar, M. (2014). Status accommodation through institutional means: India's rise and the global order. In T.V. Paul, D. W. Larson and W. C. Wohlforth, (Eds.). Status in World Politics (pp. 165-191). New York: Cambridge University Press. 
People's Daily (2018, December 25) Chinese peacekeeping forces signifies China's contribution to world peace and development. Retrieved from http://en.people.cn/n3/2018/1225/c90000-9531720.html

PMIUM [Permanent Mission of India to the UN] (2018). India and United Nations Peacekeeping and Peacebuilding. Retrieved from https://www.pminewyork.org/pdf/menu/49151pkeeping.pdf

PTI [Press Trust of India] (2018, May 30). 'In 70 Years of Peacekeeping Indian Lost Highest Number of Personnel: UN', NDTV. Retrieved from: https://www.ndtv.com/india-news/in-70-years-of-peacekeeping-india-lost-highestnumber-of-personnel-un-1859698

$\mathrm{Pu}, \mathrm{X}$. (2017). Ambivalent accommodation: status signaling of a rising India and China's response. International Affairs, 93(1), 147-163.

$\mathrm{Pu}$, Xiaoyu (2018) Asymmetrical Competitors: Status Concerns and the China-India Rivalry. In: Paul, TV (ed.) The China-India Rivalry in the Globalization Era (pp. 5574). Washington, DC: Georgetown University Press.

Qu, X. (2012, April 16). The UN Charter, the Responsibility to Protect, and the Syria Issue. China Institute of International Studies (CIIS), Beijing. Retrieved from http://www.ciis.org.cn/english/2012-04/16/content_4943041.htm. 
Renshon, J. (2017). Fighting for Status: Hierarchy and Conflict in World Politics.

Princeton: Princeton University Press.

Ringmar, E. (1996). Identity, Interest and Action: A Cultural Explanation of Sweden's Intervention in the Thirty Years War. Cambridge: Cambridge University Press.

Schaffer, T. C. (2009). The United States, India, and Global Governance: Can They Work Together? The Washington Quarterly, 32(3), 71-87.

Sreenivasan, T. P. (2008). Words, Words, Words: Adventures in Diplomacy. Delhi: Dorling Kindersley.

Strike, A. (2018, May 15). U.S.-India Joint Traning Further Strengthens Peacekeeping Missions in Africa. DipNote: U.S. Department of States Official Blog. Retrieved from: https://blogs.state.gov/stories/2018/05/15/en/us-india-joint-training-further$\underline{\text { strengthens-peacekeeping-missions-africa }}$

Sullivan, K. (2014). Exceptionalism in Indian Diplomacy: The Origins of India's Moral Leadership Aspirations. South Asia: Journal of South Asian Studies 37(4), $640-655$.

Sullivan, K. (2015). India's Ambivalent Projection of Self as a Global Power:

Between Compliance and Resistance. In K. Sullivan (Ed.) Competing Visions of India in World Politics (pp. 15-33). London: Palgrave Macmillan. 
Sullivan, K. \& Moussavi, B. (2015, January 22). India's Bid for a Permanent Seat on the UN Security Council: The Power of Distinction? Paper presented at Contemporary South Asia Seminar, University of Oxford.

UNPK [United Nations Peacekeeping] (2018a, January - December). Summary of Troop Contributing Countries By Ranking. Retrieved from https://peacekeeping.un.org/en/troop-and-police-contributors

UNPK (2018b). How we are funded. Retrieved from

https://peacekeeping.un.org/en/how-we-are-funded.

UNGA [United Nations General Assembly] (2005, September 20). ‘2005 World Summit Outcome'. Document A/60/L.1

UNGA (2015). Implementation of General Assembly resolutions 55/235 and 55/236, A/70/331/Add.1. Retrieved from http://www.un.org

UNSC [United Nations Security Council] (2011a, March 17). Document S/PV.6498. Retrieved from http://www.un.org

UNSC (2011b, October 4). Document S/2011/612. Retrieved from http://www.un.org UNSC (2012, February 4). Document S/PV.6711. Retrieved from http://www.un.org 
Vira, V. (2012, July 13). India and UN Peacekeeping: Declining Interest with Grave Implications. Small Wars Journal. Retrived from http://smallwarsjournal.com

Welsh, J. M. (2013). Norm Contestation and the Responsibility to Protect. Global Responsibility to Protect 5(2), 365-396.

Wohlforth, W. C., De Carvalho, B., Leira, H., \& Neumann, I. B. (2018). Moral authority and status in International Relations: Good states and the social dimension of status seeking. Review of International Studies, 44(3), 526-546.

Xi, J. (2014, September 18). In Joint Pursuit of a Dream of National Renewal. New Delhi. Retrieved from http://www.fmprc.gov.cn/mfa_eng/topics_665678/zjpcxshzzcygyslshdsschybdtjkstme dfsllkydjxgsfw/t1194300.shtml

Xi, J. (2015, September 28). Working Together to Forge a New Partnership of Winwin Cooperation and Create a Community of Shared Future for Mankind. New York. Retrieved from gadebate.un.org/sites/default/files/gastatements/70/70_ZH_en.pdf

Xinhua (2013). Chinese President meets UN Chief. 20 June.

Yahuda, M. (2011). International Relations of the Asia Pacific. Abingdon: Routledge, third edition. 
Zhang, W. (2012). The China wave: rise of a civilizational state. Hackensack, N.J.: World Century.

Zhang, Y. (1996). China and UN Peacekeeping: from Condemnation to Participation. International Peacekeeping, 3(3), 1-15. 